\title{
TWO CASES OF VARICELLA ENCEPHALITIS
}

BY

STANLEY GRAHAM, M.D.

(From the Department of Medical Pædiatrics, Glasgow University, and the Royal Hospital for Sick Children, Glasgow.)

Non-suppurative lesions of the nervous system in association with the common infectious fevers have been recognized as a rare occurrence for many years. Although described clinically on several previous occasions, Barlow and Penrose ${ }^{1}$ were the first to demonstrate pathologically the existence of such a lesion. They described the picture of a disseminated myelitis in a fatal case of measles which they had had under their care. Since then small groups of cases have been reported from time to time, not only in measles but in many other infections. Valentin ${ }^{2}$ in 1905 , collected from the literature 79 cases of paralysis occurring in whooping-cough. In addition, encephalitis or encephalo-myelitis has been described as a complication of smallpox, chickenpox, scarlet fever, diphtheria, mumps, influenza, typhoid fever, typhus fever, syphilis and tuberculosis. Measles and whooping-cough and, more recently, vaccination have, however, accounted for the majority of the cases. That the condition may occur at any stage of the disease, or even as a sequela after convalescence, appears to have been established.

Because varicella is one of the commoner of the infectious diseases and in the majority of instances runs a benign course, it was considered worth while to report the following cases which occurred about the same time and in which the most prominent symptom was ataxia, although signs of pyramidal tract involvement were also present.

\section{Case reports.}

Case 1.-I.H., a boy, aged 3 years, was admitted to hospital on Jan!nary 5th, 1928, because of inability to walk of three days' duration. 'The previous history was irrelevant. 'The parents stated that until three days before admission he had been in good health and that they were not aware of any skin eruption.

On examination at this time he was found to be a bright well-built boy who did not appear ill. Crusts and scars of healing varicella in approximately the second week of the disease were present. Contacts of this boy subsequently developed varicella. The most pronounced feature was the presence of an extreme degree of ataxia. There was no paralysis, and no sensory disturbances were detected. The deep reflexes were active, the plantar response was flexor, but poorly sustained ankle-clonus was obtained on the right side. The abdominal reflexes could not be elicited. The pupils reacted to light and there was no nystagmus.

Lumbar puncture revealed a clear fluid under slightly increased pressure. The cell count was 6 and the globulin test (Pandy) was positive. The Wassermann reaction of the blood was negative. 
On February 20th, although the ataxia was still marked, the boy seemed in every other way perfectly well and was dismissed home. He was seen again on March 22 nd, and was perfectly well. His mother stated that all unsteadiness disappeared within a fortnight after dismissal from the ward.

Case 2.-R.P., a boy, aged 6 years, developed varicella on May 15th, 1928, a mild attack with few constitutional symptoms. On June 3rd (i.e., nineteen days after the onset of the varicella) he went to bed quite well, but next morning he vomited, and on attempting to get out of bed found that he could not stand without support and 'swayed about like a drunk man.' 'This state of affairs persisted and on June 15th, he was admitted to hospital.

On examination, he was a well-nourished boy who did not look ill. He walked with a markedly ataxic gait and tended to fall to the right. Both legs were hypertonic, with weakness of the right. The knee-jerks were exaggerated, the plantar response was extensor on the right side and flexor on tha left, and ankle clonus was present on both sides. No sensory disturbances were detected. There was no ocular paralysis or nystagmus. There was no swelling of the optic dises although some slight fullness of the veins was noted.

Lumbar puncture showed a clear colourless fluid under slightly increased pressure. The cell count was 9 (all lymphocytes), and there was no increase in globulin. The Wassermann reaction of the blood was negative.

On July llth he was able to walk quite wall, although slowly and with care. The lineejerks were still very active, but the ankle clonus had disappeared and the plantar responses were flexor. When seen again some weeks later nothing abnormal covild be detected.

\section{Discussion.}

Two views are expressed regarding the æetiology of these nervous manifestations occurring in the infectious fevers. One is that the encephalitis and the specific fever are coincident infections, the nervous lesion being predisposed to in some way by the presence of the other disease. The other theory is that the encephalitis is the result of the action of a virus or toxin elaborated by the organism producing the infectious disease. This suggestion of a neurotropic virus is not new but has not yet received ready acceptance. The apparently increasing incidence of encephalitis following vaccination has again, however, brought the subject under discussion. Strumpell ${ }^{3}$ in 1884 suggested that just as polio-myelitis affects the anterior horn cells of the cord, so may the brain be affected by the disease which he called polio-encephalitis. In the next year, however, Marie ${ }^{4}$ suggested that the virus producing the infantile paralysis was responsible in only a certain percentage of cases of polio-encephalitis, and he stressed the association of encephalitis and the specific fevers, and indicated that the toxin of the specific fever might be the causal agent. This view has since been expressed by numerous writers. Leichtenstern ${ }^{5}$ in particular bolieved this to be the case, and both he and Nauwerk ${ }^{6}$ reported their observations on the occurrence of the disease during the pandemic of influenza at the end of last century.

Greenfield ${ }^{2}$, when recently discussing the question in connection with measles, suggested the possibility of the condition being caused by some unknown virus which spreads in epidemic waves and only produces disease when brought into activity by the exanthem. He believes that the groups of reported cases apparing at distinct intervals support this idea. It may be a significant fact that the two cases described above were observed within six months. Considering the prevalence of varicella, and its usual freedom from complica. tions, this lends some slight support to Greenfield's suggestion. 
Histologically it would appear that the lesions in encephalitis fall into two main groups. The one group, which includes polio-encephalitis and encephalitis lethargica, is characterised by the presence of well-marked perivascular 'cuffing.' In the other group embracing all the encephalitic manifestations of the virus discases including the post-vaccinal type, the cuffing although present is not so marked, the characteristic picture being produced by the presence of definite zones of perivascular demyelination. McIntosh ${ }^{8}$, however, goes so far as to say that investigations of these virus infections show that a histological picture of a certain type can be assigned to each. He also mentions that in the post-vaccinal type for example, the only toxin which has been discovered is the vaccinal one and that certain strains will produce in rabbits an encephalitis of the post-vaccinal variety. These arguments are strongly in favour of the theory that the toxin of the specific fever is the ætiological agent.

One of the main difficulties in arriving at a complete acceptance of either theory is the paucity of post-mortem material. The morbid anatomy of varicclla encephalitis is, for example, unknown, no fatal case so far having been reported.

From a perusal of the literature, it would appear that great variations in the course and prognosis may occur. Many cases obviously recover completely. Apart from the cases ending fatally in the acute stage, such conditions as hemiplegia, paraplegia, athetosis and mental defect have been described as persisting. Deafness has also been mentioned but in such cases, particularly those complicating measles, it is necessary to consider the possibility of the deafness being due to a labyrinthitis.

In varicella encephalitis the progrosis appears to be good. All the recorded casas probably number less than twenty. These have been collected in papers published by Miller and Davidson ${ }^{9}$, and more recently by Ford and Wilson ${ }^{10}$. As previously mentioned, no fatal case has as yet been reported.

\section{Conclusions.}

1. Two cases of varicella encephalitis are reported.

2. Evidence so far obtained goes to show that in the encephalitis associated with the virus diseases the ætiological agent is probably the virus of the specific infection.

3. In varicella encephalitis the prognosis is favourable.

\section{REFERENGES.}

1. Barlow, T., \& Penrose, F. G., Med-chir. Trans., Lond., 1886, LXX, 77.

2. Valentin, P., Thèses de Paris, 1901-02 (quoted by Sears, W. G., Brit. J. Child. Dis., Lond., 1929, XXVI, 178.)

3. Strümpell, A., Jahrb. f. Kinderh., Leipzig, 1885, XXII, 173.

4. Marie, P., Lect. Dis. of Spinal Cord, (Sydenham Soc.), Lond., 1895, 444.

5. Leichtenstern, H., Deutsch. Med. Wochnschr., Leipzig, 1892, XVIII, 39.

6. Nauwerk, Prof., Ibid., Leipzig, 1895, XXI, 393.

7. Greenfield, J. G., Brain, Lond., 1929, LII, 171.

8. MeIntosh, J., Brit. Med. J., Lond., 1928, ii, 334.

9. Miller, R., \& I)avidson, J., Brit. J. Child. Dis., Lond., 1914, XI, 15.

10. Ford, F. R., \& Wilson, R. E., Bull. Johns Hopkins Hosp., Baltịore, 1927, XI, 337, 